\title{
DAŽNAI SERGANTIS VAIKAS - AR NESUTRIKĘS JO IMUNITETAS
}

\author{
DR. RADVILE் MALICKAITÉ
}

VU ŠIRDIES IR KRAUJAGYSLIŲ LIGŲ KLINIKOS ŠIRDIES CHIRURGIJOS CENTRAS

\begin{abstract}
Reikšminiai žodžiai: imuninẻ sistema, infekcijos, imunodeficitai.
Santrauka. Visus imunodeficitus jungiantis bruožas - padidejęs imlumas infekcijoms. Daugeliu atvejų imunodeficitas būna igytas, antrinis. Pirminis imunodeficitas (PID) yra imuninės sistemos ląstelių vystymosi, diferenciacijos ir brendimo sutrikimų pasekmė, jų dažnumas Europoje - 1,33 iš 10 tūkst. gyv.; šiuo metu aprašyta apie šimtas PID. Imuniniai defektai gali būti sąlyginai skirstomi pagal pažeistas funkcines imuninès sistemos dalis siejant su būdingais klinikiniais simptomais arba pagal juos lemiančius genų defektus. Antrinis imunodeficitas gali išryšketti po traumu, operacijų, esant nepakankamai mitybai, sergant piktybinėmis ligomis (pvz.: leukemija, limfoma, daugine mieloma, infekcinėmis ligomis, taip pat ir žmogaus imunodeficito virusu), dèl įvairių vaistų poveikio (pvz.: gydant chemoterapiniais preparatais, imunosupresoriais po organų persodinimo, steroidais arba nesteroidiniais vaistais nuo uždegimo, antibiotikais, po spindulinio gydymo, ypač galvos ir kaklo srityje.
\end{abstract}

\section{IVADAS}

Imunitetas yra organizmo apsaugos būdas, kurio pagrindinè užduotis - išsaugoti organizmo vidinę homeostazę, apginti nuo visko, kas jam genetiškai svetima. Žmogaus imuninès sistemos visavertiškumas priklauso nuo adekvataus nespecifinių ir specifinių imuninių veiksnių veikimo bei imuniniụ ląsteliụ skaičiaus ir jụ funkcijos. Imuninę žmogaus sistemą galima sąlygiškai suskirstyti $i$ keturias funkcines dalis: fagocitu (neutrofilų, makrofagụ) lemiamą imuninị atsaką, humoralinị, arba B limfocitu lemiamą imunitetą, ląstelinị, T limfocitu lemiamą imunitetą, ir komplemento sistemą. Esant humoralinio imuniteto nepakankamumui, infekcijos priežastis dažniausiai būna piogeninès bakterijos, ląstelinio - virusai ir viduląsteliniai mikroorganizmai, fagocitozès - piogeninès bakterijos ir grybeliai, taigi kiekviena imuninès sistemos sudedamoji dalis turi savo specifinę funkciją, o pažeista - specifinę klinikinę raišką.

Dažnos infekcinès ligos, ypač vaikystëje, - rimta diagnostiné problema: gydytojas turi nuspręsti, ar tai pirminio imunodeficito (PID) pasekmé ar normos variantas. Literatūroje yra nuorodụ, kad imuniniu požiūriu sveikiems vaikams iki 6-10 viršutinių kvėpavimo takụ infekcijos epizodu per metus yra normalu; infekcijos dažnesnès 6-12 mènesių amžiuje (skylant motinos IgG), taip pat tada, kai vaikas pradeda lankyti vaiku darželi ar mokyklą ir susiduria su jo imuninei sistemai naujais patogenais $[1,2]$. Kita vertus, delsti diagnozuojant PID negalima, gydymas turi būti pradètas laiku, nes dèl dažnų infekcijų gali būti negrịžtamai pažeisti ligonio vidaus organai ir nukentèti raida.

\section{KARTOTINĖS INFEKCIJOS RIZIKOS VEIKSNIAI}

Pagrindiniai kartotinès infekcijos, ypač apatinių kvèpavimo takŭ, rizikos veiksniai yra amžius, neišnešiotumas, tèvų, ypač motinos, rūkymas, didelè šeima ar blogos gyvenimo sąlygos, taip pat igimtos anomalijos, ịvairūs imuninès sistemos defektai [1]. Imuninès sistemos negebejimas išvystyti normalaus imuninio atsako į antigenus vadinamas imunodeficitu. Reikia turèti omenyje, kad imuninès sistemos silpnumas nebūtinai yra lemtas imuninès sistemos ląsteliụ vystymosi, diferenciacijos ir brendimo sutrikimų, jis gali būti blogos mitybos, streso, lètinès ligos (pvz.: anemijos, astmos, širdies ligos) padarinys, o dažnas infekcijas gali skatinti blogi tẻvų higienos igūdžiai ar aplinkos veiksniai.

\section{ANTRINIS IMUNODEFICITAS}

Daugeliu atvejų imunodeficitas būna igytas, arba antrinis, gali atsirasti po traumų ar nudegimų, po narkozės arba didelių operacijų, esant nepakankamai mitybai (ypač stingant baltymų), ìvairiems metabolizmo sutrikimams, sergant piktybinèmis ligomis, infekcinèmis 
ligomis (virusinėmis, kaip antai: ŽIV, CMV, EBV, tymais; bakterinèmis, parazitinėmis, tuberkulioze, kokcidiomikoze), dèl ịvairių vaistų poveikio (pvz.: gydant chemoterapiniais preparatais, imunosupresoriais po organu persodinimo, steroidais arba nesteroidiniais vaistais nuo uždegimo, antibiotikais, po spindulinio gydymo, ypač galvos ir kaklo srityje). Aprašomi su dideliu fiziniu krūviu [3,4], psichologiniu stresu, socialine izoliacija susiję imuninès sistemos deficitai. Tokiomis sąlygomis galimas ne tik infekcijų padažnejjimas, bet ir laboratoriškai nustatomas deficitas, kai T limfocitų pagalbininkų (CD4+) skaičius net nesiekia 200 ląst. $/ \mathrm{mm}^{3}$, o tai gali skatinti itarti AIDS. Antrinio imunodeficito trukmè labai ịvairi - iki dviejų savaičių po didelès operacijos, iki 6-9 mènesių po EBV infekcijos. Antrinio imunodeficito atvejais gali būti sutrikusi imuniniam atsakui svarbių molekulių gamyba (pvz.: imunoglobulinų, citokinų stoka po imunosupresinio gydymo, badavimo, stingant vitaminų arba mikroelementų), jų gali būti daugiau prarandama (pvz., organizmas netenka daug IgG po nudegimų, inkstų funkcijos nepakankamumo arba nefrozinio sindromo atveju, sunkios enteropatijos arba žarnyno uždegimo ligos atveju), gali būti sutrikdyta imunokompetentinių ląstelių proliferacija (pvz., dèl imunosupresorių poveikio), imuninę sistemą gali pažeisti autoimuninès ligos.

\section{LAIKINAS IMUNODEFICITAS}

Neišnešiotiems naujagimiams būdingas transplacentinio (motinos) IgG deficitas, labai mažas IgM ir IgA kiekis; dèl hipogamaglobulinemijos ir komplemento aktyvinimo sutrikimų būdingi opsonizacijos defektai. Išnešioti naujagimiai gimsta turèdami pakankamai IgG, bet infekcijų atveju antikūnų atsakas būna lètas, ypač ì bakterijų sienelès lipopolisacharidus; IgM bei IgA kiekis nesiekia suaugusiesiems būdingų ribų, neutrofilų mobilizacija iš kaulų čiulpų lèta, ląstelių adherentiškumas, chemotaksis, mikrobicidinis neutrofiluc aktyvumas mažas. Galimas natūraliųjų žudikų (NK) funkcijos nepakankamumas, ịvairūs ląstelinio atsako defektai, ypač dèl antigeną pristatančių ląstelių (APC) funkcijos nepakankamumo. Motinos IgG skylant, 3-6 mèn. kūdikių kraujyje IgG kiekis būna mažiausias (apie $0,35 \mathrm{~g} / \mathrm{l}$ ) - tai fiziologinès hipogamaglobulinemijos periodas, kuris maždaug 5-8 proc. kūdikių, ypač neišnešiotiems, gali pailgèti ir tęstis iki 2-4 metų. Kūdikių organizme imunoglobulinai sintetinami lèčiau negu suaugusiųjų, manoma, dèl nepakankamos B limfocitų kooperacijos su CD4+ limfocitais. Sekrecinio IgA, imunoglobulino, garantuojančio specifinę gleiviniu apsaugą, kiekis kraujyje suaugusio žmogaus ribą pasiekia tik 5-7 gyvenimo metai, o dažnai dar vẻliau paauglystèje.

\section{PIRMINIS IMUNODEFICITAS}

Europos pirminio imunodeficito draugijos (ESID) duomenimis, pirminio imunodeficito atvejų dažnumas Europoje yra 1,33 iš 10 tūkst., t. y. Europos Sąjungos šalyse gyvena apie 1,5 milijono PID sergančių asmenų. Europoje PID pasiskirstęs taip: 67 proc. - ID, kai vyrauja antikūnų defektai, 18 proc. - T ląstelių ir mišrūs ID, 7 proc. - fagocitu, 6 proc. - komplemento, 2 proc. kiti ID. Šios ligos dažniau pasitaiko berniukams - jie sudaro net 70 proc. pacientų (dalis PID paveldima su $\mathrm{X}$ chromosoma susijusiu būdu).

Pirminis imunodeficitas - imuninès sistemos ląstelių vystymosi, diferenciacijos ir brendimo sutrikimų padarinys, jis būna paveldètas arba igimtas, dažniausia priežastis - paveldètos arba de novo genų, koduojančių imuninès sistemos elementus, mutacijos. Kuo ankstesniame ląstelès diferenciacijos etape yra defektas, tuo sunkesni imuniniai, o kartu ir klinikiniai imunodeficito padariniai. Šiuo metu aprašyta apie šimtas PID; genų defektas nustatytas tik 30-čiai jų [5-10].

Bendros imunodeficito klasifikacijos kol kas nèra. Imuniniai defektai gali būti sąlyginai skirstomi pagal pažeistas funkcines imuninès sistemos dalis siejant su būdingais klinikinis simptomais arba pagal juos lemiančius genų defektus.

Visus PID jungiantis bruožas - padidejęs imlumas infekcijoms, t. y. dažnos eilinès ausų, sinusų, plaučių infekcinès ligos, kartojasi virškinamojo trakto infekcinès ligos. Kai imuninès sistemos kompetencija nepakankama, ne tik dažnai sergama infekcinèmis ligomis, bet ir nepavyksta greitai sunaikinti infekcinio agento tinkamai gydant, vietinès infekcijos išplinta, atsiranda oportunistiniu infekcijų, infekcijų vieta nebūdinga (meningitas, osteomielitas, pasikartojantys gilūs abscesai). Septicemija, galvos ir nugaros smegenų dangalu uždegimas, kaulų ir kaulų čiulpų infekcijos galimos ir normalią imuninę sistemą turintiems vaikams, tačiau jei jos pasikartoja daugiau negu vieną kartą, derètų ịtarti ID. Infekcijos būna užsitęsusios, atsinaujinančios, linkusios tapti lètinemis; nepaisant gydymo antibiotikais visiškai klinikiniai požymiai tarp ciklų išnyksta retai. Dèl nuolatinių infekcijų atsilieka vaiko raida, lètẻja augimas, negrižtamai kinta organai. Be to, esant pirminiam imunodeficitui dažniau susergama kai kurių lokalizacijų navikais, autoimuninėmis ligomis.

Tik kai kurie imunodeficito sindromai turi jiems būdingą klinikinę raišką, todèl ligos diagnozuojamos pernelyg retai ir pernelyg vèlai. Nesant tikslios diagnozès ir dèl to tinkamai negydant, galimos sunkios, gyvybei pavojingos infekcinès komplikacijos, negrižtami organų pokyčiai ir invalidumas.

Renkant anamnezę išskirtinị dėmesị reikia atkreipti i tai, kokio amžiaus buvo vaikas, kai pradejo kartotis infekcijos. Pirmaisiais 6-8 gyvenimo mènesiais naujagimiai yra saugomi per placentą iš motinos gautų IgG, vẻliau pasyvi apsauga nyksta ir gali pasireikšti antikūnų ID požymių. Tuo periodu gali išryškèti su X chromosoma susijusi agamaglobulinemija bei ID, kai yra padidejęs IgM kiekis (hiper IgM sindromas). Išimtis iprastinis kintamas imunodeficitas (angl. Common variable immunodeficiency, CVID), arba suaugusiųju hipogamaglobulinemija: imuniniai ir klinikiniai pokyčiai prasideda vèliau nei nuo antrųjų gyvenimo metų, bet 
dažniausiai antrą trečią dešimtmetị. T ląstelių stoka, pavyzdžiui, sunkus mišrus imunodeficitas (SCID), yra gyvybei pavojingas grịžtamųjų infekcijų, diarèjos, dermatito ir augimo sutrikimo sindromas, nulemtas molekulinių genų defektų, dèl kurių sutrinka T ir/arba B ląstelių funkcija. Kliniškai būdingiausia pradžia - maždaug trečias gyvenimo mènuo, kai prasideda neịprastai sunkios infekcijos, taip pat ir sukeliamos oportunistinių sukèlejų. Bet kurios formos SCID - skubios pediatrinès pagalbos reikalinga liga, nes naujagimio išgyvenimas priklauso nuo greitos diagnostikos ir nepavèluoto kaulų čiulpu persodinimo, arba galbūt genu terapijos pradžios. T limfocitai yra būtini užtikrinti pagalbinę funkciją B ląstelèms, todèl vaikams, kuriems yra T ląstelių sutrikimų, jau pirmaisiais gyvenimo mènesiais gali išryškèti klinikinių ląstelinio ID požymių, o suskilus motinos antikūnams - ir humoralinio.

Esant fagocitu nepakankamumo sindromui, ligos klinikinius požymius nulemia fermentų sistemų, reikalingų laisviesiems deguonies radikalams gaminti, nevisavertiškumas, taigi sutrinka fagocituotų bakterijų naikinimas. Klinikinè eiga priklauso nuo formos: galimos ankstyvos mirtys, bet yra galimybė išgyventi iki suaugusiojo amžiaus, būdingos gilios kepenų, perirektalinès, plaučių pūlinès infekcijos, osteomielitas. Ligonis „tirpsta“ infekcijoje, kartojasi furunkulai, vidaus

\section{THE CHILD IS FREQUENTLY SICK - IS HIS IMMUNITY DISTURBED}

\section{RADVILĖMALICKAITÉ \\ CLINIC OF CARDIOVASCULAR DISEASES \\ HEART SURGERY CENTRE \\ VILNIUS UNIVERSITY}

Keywords: immune system, infection, immunodeficiency.

Summary. In medicine, immunodeficiency is a state in which the immune system's ability to fight infectious disease is compromised or entirely absent. Most cases of immunodeficiency are acquired, "secondary" but some people (about 1.33/10 000) are born with defects in the immune system, or primary immunodeficiency (PID). There are over 100 recognized PID syndromes; they are generally grouped by the part of the immune system that is malfunctioning, such as lymphocytes or granulocytes. Immune deficiency may also be the result of particular external processes or diseases; common causes for secondary immunodeficiency are malnutrition, aging and particular medications (e.g. chemotherapy, disease-modifying antirheumatic drugs, immunosuppressive drugs after organ transplants, glucocorticoids).

Many specific diseases directly or indirectly impair the immune system. This include many types of cancer, particularly those of the bone marrow and blood cells (leukemia, lymphoma, multiple myeloma), and certain chronic infections. Immunodeficiency is also the hallmark of acquired immunodeficiency syndrome (AIDS), caused by the human immunodeficiency virus (HIV). organų abscesai, sepsis, būdinga anemija, infekcijos kartojasi, ilgai trunka, atsparios gydymui antibiotikais.

Infekciją sukèlusių bakterijų identifikavimas taip pat gali duoti vertingos informacijos apie ID pobūdị. Esant izoliuotam antikūnų ID, dažniau sergama piogeninėmis sinusų ir plaučių ligomis, sukeltomis apvalkalą turinčių mikroorganizmų (pvz.: Streptococcus pneumoniae ir pyogenes, Haemophilus influenzae, Staphylococcus aureus), būdinga tai, kad tokie patogenai atkakliai laikosi kvejpavimo takų skrepliuose. Ligoniai jautrūs enterovirusų invazijai, ypač ì centrinę nervų sistemą, didesnei pusei ligonių pasireiškia gastroenteritai (sukèlejai Gardia lamblia, rotavirusai), lètinè diarejja ir kartu svorio mažejimas. Ląstelinio imunodeficito atvejais dažnesnès gramneigiamų mikroorganizmų sukeliamos infekcijos, mikobakterinès infekcijos, dažnai pasitaiko grybelinės, pirmuonių ir virusinès, ypač Herpes viruso, infekcijos. Infekcijos, sukeltos katalazei teigiamų kokų, Staphylococcus aureus, taip pat Serratia marcescens, Candida arba Aspergillus, dažnos esant fagocitozès sutrikimams. Neisseria tipo bakterijų sukeliamos kartotinès infekcijos būdingos ligoniams, kuriems yra komplemento komponentu nepakankamumas; tokie ligoniai yra imlūs bakterinèms sąnarių ligoms, galvos ir nugaros smegenų dangalų uždegimui, galimas sunkios eigos sepsis.

\section{LITERATŪRA}

1. Courist J. Assessment of the child with recurrent chest infection. British Medical Bulletin 2002;61:115-32.

2. Kovarik J, Siegrist C-A. Immunity in early life. Immunology Today 1998;19(4):150-2.

3. Nieman DC. Current perspectives on exercise immunology. Curr Sports Med Rep 2003;2(5):239-42.

4. Malickaitè R, Milašius K, Dadelienè R. Fizinio krūvio ir maisto papildụ įtaka imuninès sistemos rodikliams. Laboratorinè medicina 2003:4(20):27-30.

5. Buckley RH. Advances in immunology: primary immunodeficiency diseases due to defects in lymphocytes. The New England Journal of Medicine 2000;343(18):1313-24

6. Bonilla FA, Berstein IL, Khan DA, Ballas ZK et al. Practice parameter for the diagnosis and management of primary immunodeficiency. Annals of Allergy, Asthma and Immunology 2005;94:S1-S63.

7. Malickaitè R. Imunodeficito būklès. Vaiku ligos, IV tomas. Parengta vadovaujant Raugalei A. ISBN 9986-19-860-7. Vilniaus universiteto leidykla; 2005. p. 339-64

8. Burke W. Genetic testing. The New England Journal of Medicine 2004;347(23):1867-75.

9. Chinen J, Puck JM. Perspectives of gene therapy for primary immunodeficiencies. Current Opinion in Allergy and Clinical Immunology 2004;4(6):523-7. 